\title{
EARTHQUAKE SOURCE MECHANISMS AND PLATE TECTONICS
}

\author{
Hiroo Kanamori
}

Seismological Laboratory, California Institute of Technology, Pasadena, California 91125

This review and the accompanying references will be concerned mainly with earthquake source studies pertinent to plate tectonics. Studies on geological problems, lithospheric flexure and mantle convection are discussed in other reviews in this volume.

In the earlier stage of the development of plate tectonics, the distribution of earthquakes and the geometrical configuration of earthquake source mechanisms played an important role. As more sophisticated techniques for retrieving earthquake source parameters (synthetic seismogram method for both body and surface waves, inversion method, matching filter method, etc.) were developed, emphasis in the last four years was placed on the determination of not only the geometry of the source but also more quantitative parameters such as the stress drop, the amount of slip, the complexity, the strength of non-isotroplc components, and the spectral characteristics. Also significant emphasis was placed on intraplate earthquakes and events on continental plate boundaries.

The results for the individual earthquakes are of fundamental importance for developing and constraining varfous plate tectonics models. For example, a number of mechanism solutions have been included in the new synthesis of global plate motion [Minster and Jordan, 1978]. Since it is not practical to review the results for the individual events, a fairly complete list of the papers pertinent to the source mechanism study is prepared and listed in the reference.

The orientation and the magnitude of the stress associated with intraplate events are among the key parameters in constraining the driving mechanism of plates [e.g., Solomon et al., 1975; Richardson et al., 1976]. Richardson et al. [1976] found that intraplate stresses calculated for models in which viscous drag at the base of the lithosphere acts in the direction of absolute plate velocity are in much poorer agreement with observed stresses than are those for models in which drag resists plate motions.

Copyright 1979 by the American Geophysical Union.
Sykes [1978] summarized the distribution of intraplate earthquakes and of igneous rocks In a plate tectonic framework. One of the conclusions is that intraplate earthquakes tend to be concentrated along preexisting zones of weakness within areas affected by the youngest orogenesis that predates the opening of the present oceans.

Because of the difficulty of determining the fault dimension of intraplate events, the estimates of stress drop are still uncertain. Existing data indicate [e.g., Kanamori and Anderson, 1975; Richardson et al., 1977] that although the stress drop of intraplate events may be slightly (factor of 2 or 3 ) higher than that of inter-plate events, no order-of-magnitude difference exists between them. A relatively low stress drop, about 100 bars, for intraplate earthquakes is consistent with inferences from current models of the plate tectonic driving mechanism. Some questions have been raised about whether intraplate events represent the state of stress in the plate or the effect of local topographic features in the plate [Stein, 1978].

A large number of studies were made on seismotectonics of varlous regions. Papers on this subject are listed in the reference under category "Regional Tectonics". A recent development in this field is the study of continental tectonics [e.g., Molnar and Tapponnier, 1975; Bird et al., 1975; Chen and Molnar, 1977; Menke and Jacob, 1976; Armbruster et al., 1978; Chandra, 1978].

Armbruster et a1. [1978] studied the northwestern termination of the Himalayan mountain front and found that the composite mechanisms of earthquakes in this area are compatible with the north-south convergence between the Indian and Eurasian plates inferred from plate tectonics.

Molnar and Tapponnter [1975] concluded on the basis of geomorphological and seismological evidence that the large-scale tectonics of Asia are a result of the India-Eurasia continental collision. They interpreted the marked decrease in the relative motion between India and Eurasia to be a result of the collision.

The amount of seismic slip along plate 
boundaries has been determined from the seismic moment of large earthquakes [Kanamori, 1977]. A substantial discrepancy between the computed seismlc slip rate and the rate inferred from the instantaneous plate motion has been found for some plate boundaries. This discrepancy suggests that either a large part of plate motion at plate boundaries is aseismic or the current plate motion is substantially different from that inferred from plate tectonics. For several earthquakes, evidence has been presented for the existence of large amounts of aseismic motion suggesting that slip at plate boundaries does involve aseismic motion [Kanamori and Anderson, 1975; Thatcher, 1975; Sacks et al., 1978; Kanamori and Stewart, 1979]. On the other hand, hang-up of plate motion due to subduction of buoyant oceanic 1 ithospheres has been suggested to account for the lack of great earthquakes along some plate boundaries (e.g., the Marianas) [Kelleher and McCann, 1976; Vogt et al., 1976].

The relation between large earthquakes and varlous global processes such as rotation of the earth, the earth's polar motion including Chandler wobble and transient plate motions has been a subject of vigorous research [Anderson, 1975; Press and Briggs, 1975; $0^{\prime}$ Connel1 and Dzlewonsk1, 1976; Smith, 1977]. It appears that the effect of earthquakes, with their selsmic component alone is too small to affect the earth's polar motion significantly. Wilson and Haubrich [1977] concludes that the earthquake portion of the Chandler wobble excltation is smaller than $25 \%$ while the contribution of meteorological variation appears to be not less than $25 \%$. However, in view of the possible aseismic component of earthquake deformation, a causal relation between earthquakes and Chandler wobble should not be completely dismissed [O'Connell and Dziewonsk1, 1976].

The response of the viscous asthenosphere to the transient displacement caused by a large earthquake has been studied in order to determine the constitutive law for the asthenosphere and its effective viscosity [Anderson, 1975; Melosh, 1976; Savage and Prescott, 1978; Thatcher and Rundle, 1979]. Anderson [1975] used a simple model of an elastic lithospheric plate riding on a viscous asthenosphere to show that most of the plate rotions near plate boundarles occur during short periods of time after a large decoupling earthquake. This accelerated plate motion may have a significant effect on the excitation of Chandler wobble.

Melosh [1976] used a migration pattern of the aftershocks of the 1965 Rat Is. earthquake to determine the constitutive law for the asthenosphere and concluded that a nonlinear constitutive relation $\dot{\varepsilon}$ (strain rate) $\sigma(\text { stress })^{\mathrm{n}} \quad(\mathrm{n}=3$ to 4$)$ is most appropriate. However, Savage and Prescott [1978] argue that a Iinear model is capable of producing the observed migration pattern. In order to resolve this problem, direct measurements of transient deformation after a large decoupling earthquake would be extremely important.

Rundle and Jackson [1977] and Thatcher and Rundle [1979] used a viscous asthenosphere model to explain the time dependent deformation after the 1906 San Francisco earthquake and the 1946 Nankaido earthquake.

Development in the method of earthquake location (e.g., master-event method, relativelocation method, joint-hypocenter determination) allowed a very high resolution analysis of the geometry of various selsmic zones, in particular Benioff zones [Billington and Isacks, 1975; Barazangi and Isacks, 1976; Engđah1, 1977; Isacks and Barazang1, 1977; Cardwell and Isacks, 1978]. One of the significant results is the discovery of lateral segmentation of Benioff zones in South America. Isacks and Barazangi found a remarkable correlation between a nearly flat Benioff zone beneath South America and the absence of Quatemary volcanoes.

James [1978] proposed an alternative mode1 in which the Nazca plate dips at an angle of about $30^{\circ}$. This model is based on the depth of the upper boundary of the descending plate Inferred from converted seismic phases and on the anelasticity structure of central Peru [Snoke et al., 1977; Sacks, 1977]. James argued that whether the Benioff zone beneath central Peru is flat or not is not yet resolved.

Mechanism studies of great earthquakes suggest that truly great earthquakes occur only in subduction zones without actively opening back-arc basins while subduction zones with active back-arc basins are completely lacking in great earthquakes. Uyeda and Kanamori [1979] interpreted this correlation in terms of either a difference in the degree of intra-plate coupling or a difference in the velocity of the landward plate.

Acknowledgments. The study was supported by Grant No. EAR78-11973 from the Earth Sciences Division, National Science Foundation. Contribution Number 3227, Division of Geological and Planetary Sciences, California Institute of Technology, Pasadena, California 91125.

\section{REFERENCES}

\section{Source Mechanism Studies}

Bhattacharya, B., and N. N. Biswas, Implicatfons of north Pacific plate tectonics in central Alaska: Focal mechanisms of earthquakes, Tectonophysics, 53, 99-130, 1979.

Buland, R. and F. Gilbert, Matched filtering for the seismic moment tensor, Geophys. Res. Lett., 3, 205-206, 1976.

Burdick, $\bar{L}$. J., and G. R. Mellman, Inversion of the body waves from the Borrego mountain earthquake to the source mechanism, Seismol. Soc. Am., Bul1., 66, 1485-1499, 1976.

Butler, R. G. S. Stewart, and H. Kanamori, The July 27, 1976 Tangshan, China earthquake A complex sequence of intraplate events, Seismol. Soc. Am., Bull., 69, 207-220, 1979.

Cardwell, R. K., and B. L. Isacks, Investigation of the 1966 earthquake series in northern China using the method of joint epicenter determination, Seismol. Soc. Am., Bul1., 66, 1965-1982, 1976.

Chandra, U., Fault-plane solution and tectonic implications of the Pattan, Pakistan earth- 
quake of December 28, 1974, Tectonophysics, 28, T19-T24, 1975.

Chen, T. and D. W. Forsyth, A detailed study of two earthquakes seaward of the Tonga trench: Implications for mechanical behavior of the oceanic 1ithosphere, J. Geophys. Res., 83, 4995-5003, 1978.

Chung, W. Y., and H. Kanamori, Source process and tectonic implications of the Spanish deep-focus earthquake of March 29, 1954, Phys. Earth Planet. Inter., 13, 85-96, 1976.

Ebe1, J. E., L. J. Burdick and G. S. Stewart, The source mechanism of the August 7, 1966, El Golfo earthquake, Seismol. Soc. Am., Bu11., 68, 1281-1292, 1978.

Fukao, Y., Tsunami earthquakes and subduction processes in 1sland arcs, J. Geophys. Res., in press, 1979.

Fukao, Y. and M. Furumoto, Stress drop, wave spectrum and recurrence interval of great earthquakes - Implication from the Etorofu earthquake of Nov. 6, 1958, R. Astron. Soc., Geophys. J., in press, 1979.

Gilbert, F. and A. M. Dziewonski, An application of normal mode theory to the retrieval of structural parameters and source mechanisms from seismic spectra, Phil. Trans. R. Soc. Lond. A, 278, 187-269, 1975.

Hart, R. S., R. Butler, and H. Kanamori, Surface wave constraints on the August 1 , 1975, Oroville earthquake, Seismo1. Soc. Am., Bul1., 67, 1-7, 1977.

Hartzel1, S. H., and J. N. Brune, Source parameters for the January 1975 Brawley-Imperial Valley earthquake swarm, Pure Applied Geophysics, 115, 333-355, 1977.

Hartzell, S. H., J. N. Brune, and J. Prince, The October 6, 1974 Acapulco earthquake: An example of the importance of short period surface waves in strong ground motion, Selsmol. Soc. Am., Bull., 68, 1663-1677, 1978.

Heaton, T. H., and D. V. Helmberger, A study of the strong ground motion of the Borrego Mountain, California, earthquake, Seismol. Soc. Am., Bul1., 67, 315-330, 1977.

Herrmann, R. B., A seismological study of two Attica, New York earthquakes, Seismol. Soc. Am., Bul1., 68, 641-651, 1978.

Herrmann, R. B., Surface wave focal mechanisms for eastern North American earthquakes with tectonic implications, J. Geophys. Res., in press, 1979 .

Herrmann, R. B., G. W. Fischer, and J. E. Zol1weg, The June 13, 1975 earthquake and its relationship to the New Madrid seismic zone, Seismol. Soc. Am., Bu11., 67, 209-218, 1977.

Herrmann, R. B., and Jose-Antonia Canas, Focal mechanism studies in the New Madrid seismic zone, Seismol. Soc. Am., Bul1., 68, 1095$1102,1978$.

Horner, R. B., A. E. Stevens, H. S. Hasegawa, and G. LeBlanc, Focal parameters of the July 12, 1975, Maniwaki, Quebec, earthquake - an example of intraplate seismicity in eastern Canada, Seismol. Soc. Am., Bull., 68, 619$640,1978$.

Johnson, C. E., and D. M. Hadley, Tectonic Implications of the Brawley earthquake swarm, Imperial Valley, California, January 1975, Seismo1. Soc. Am., Bul1., 66, 1133-1144, 1976.
Kanamori, H. and G. S. Stewart, Seismological aspects of the Guatemala earthquake of February 4, 1976, J. Geophys. Res., 83, 3427$3434,1978$.

Langston, C. L., A body wave inversion of the Koyna, India earthquake of December 10, 1967, and some implications for body wave focal mechanisms, J. Geophys. Res., 81, 2517-2529, 1976.

Langston, C. A., The February 9, 1971 San Fernando earthquake: A study of source finiteness in teleseismic body waves, Seismol. Soc. Am., Bul1., 68, 1-29, 1978.

Langston, C. A., and D. E. Blum, The April 29, 1965, Puget Sound earthquake and the crustal and upper mantle structure of western Washington, Seismol. Soc. Am., Bu11., 67, 693-711, 1977.

Langston, C. A., and R. Butler, Focal mechanism of the August 1, 1975 Oroville earthquake, Seismo1. Soc. Am., Bu11., 66, 1111-1120, 1976.

Malone, S. D., G. H. Rothe, and S. W. Smith, Details of microearthquake swarms in the Columbia basin, Washington, Seismol. Soc. Am., Bul1., 65, 855-864, 1975.

Mills, J. M., and T. J. Fitch, Thrust faulting and crust-upper mantle structure in east Australia, R. Astron. Soc., Geophys. J., 48 351-384, 1977 .

Mitchel1, B. J., J. E. Zollweg, J. J. Kohsmann, C. C. Cheng, and E. J. Haug, Intra-plate earthquakes in the Svalbard archipelago, J. Geophys. Res., in press, 1979.

Munguia, L., M. Reichle, A. Reyes, R. Simons, and J. Brune, Af tershocks of the $8 \mathrm{July}, 1975$ Canal de las Ballenas, Gulf of California, earthquake, Geophys. Res. Lett., 4 , 507-509, 1977.

North, R. G., Seismic moment, source dimensions, and stresses associated with earthquakes in the Mediterranean and Middle East, R. Astron. Soc., Geophys. J., 48, 137-161, 1977.

Okal, E. A., A surface-wave investigation of the rupture mechanism of the Gobi-Altai (Dec. 4, 1957) earthquake, Phys. Earth Planet. Int., $12,319-328,1976$.

Okal, E. A., The July 9 and 23, 1905, Mongolian earthquakes: A surface wave investigation, Earth Planet. Sci. Lett., 34, 326-331, 1977.

okal, E. A., and R. J. Geller, on the observability of isotropic seismic sources: The July 31, 1970, Colombian earthquake, Phys. Earth Planet. Int., in press, 1979.

Patton, $H .$, A note on the source mechanism of the southeastern Missouri earthquake of October 21, 1965, J. Geophys. Res., 81, 1483$1486,1976$.

Rial, J. A., The Caracas, Venezuela earthquake of July 1967: A multiple source event, J. Geophys. Res., 83, 5405-5414, 1978.

Reichle, M. S., G. F. Sharman, and J. N. Brune, Sarobuoy and teleselsmic study of Gulf of California transform fault earthquake sequences, Seismo1. Soc. Am., Bu11., 66, 1623-1641, 1976.

Rogers, G. C., and H. S. Hasegawa, A second look at the British Columbia earthquake of June 23, 1946, Seismol. Soc. Am., Bul1, 68, 653$675,1978$.

Rogers, A. M., and W. H. K. Lee, Seismic study of earthquakes in the Lake Mead, Nevada- 
Arizona region, Seismol. Soc. Am., Bul1., 66 , $1657-1681,1976$.

Stauder, W., Subduction of the Nazca plate under Peru as evidenced by focal mechanisms and by seismicity, J. Geophys. Res., 80, 1053-1064, 1975.

Stauder, W., and L. Mualchin, Fault motion in the larger earthquakes of the KurileKamchatka arc and of the Kurile-Hokkaido corner, J. Geophys. Res., 81, 297-308, 1976.

Stein, S., An earthquake swarm on the ChagosLaccadive ridge and its tectonic implications, R. Astron. Soc., Geophys. J., 55, 577-588, 1978.

Stewart, G. S., and S. N. Cohn, The August 16, 1976, Mindanao, Philippine earthquake $\left(M_{s}=\right.$ 7.8) - Evidence for a subduction zone south of Mindanao, R. Astron. Soc., Geophys. J., in press, 1979 .

Thatcher, W., Strain accumulation and release mechanism of the 1906 San Francisco earthquake, J. Geophys. Res., 80, 4862-4872, 1975.

Toksöz, M. N., J. Nabelek, and E. Arpat, Source properties of the 1976 earthquake in east Turkey: A comparison of field data and teleselsmic results, Tectonophysics, 49, 199-205, 1978.

\section{Synthesis and Models}

Bird, P., Initiation of intracontinental subduction in the Himalaya, J. Geophys. Res., $83,4975-4987,1978$.

Bischke, R. E., Sceular horizontal displacements: A method for predicting great thrust earthquakes and for assessing earthquake risk, J. Geophys. Res., 81, 2511-2516, 1976.

Burr, N. C., and S. C. Solomon, The relationshlp of source parameters of oceanic transform earthquakes to plate velocity and transform length, J. Geophys. Res., 83, 1193-1205, 1978.

Das, S., and K. AkI, Fault plane with barriers: A versatile earthquake model, J. Geophys. Res., 82, 5658-5670, 1977.

Forsyth, D., and S. Uyeda, On the relative importance of the driving forces of plate motion, R. Astron. Soc., Geophys. J., 43 , 163-200, 1975 .

Hill, D. P., A model for earthquake swarms, J. Geophys. Res., 82, 1347-1352, 1977.

Jischke, M., On the dynamics of descending lithospheric plates and slip zones, J. Geophys. Res., 80, 4809-4813, 1975.

Kanamor1, H., and D. L. Anderson, Theoretical basis of some empirical relations in seismology, Selsmol. Soc. Am., Bul1., 1073-1095, 1975.

Kaula, W. M., Absolute plate motions by boundary velocity minimizations, J. Geophys. Res., 80, $244-248,1975$.

Mendiguren, J. A., and F. M. Richter, On the origin of compressional intraplate stresses in South America, Phys. Earth Planet. Inter., $16,318-326,1978$.

Minster, J. B., T. H. Jordan, Present-day plate motions, J. Geophys. Res., 83, 5331-5354, 1978.

Oldenburg, D. W., and J. N. Brune, An explanation for the orthogonality of ocean ridges and transform faults, J. Geophys. Res., 80 , 2575-2585, 1975.

Richardson, R. M., and S. C. Solomon, Apparent stress and stress drop for intraplate earthquakes and tectonic stress in the plates, Pure App1. Geophys., 115, 317-331, 1977.

Richardson, R. M., S. C. Solomon, and N. H. Sleep, Intraplate stress as an indicator of plate tectonic driving forces, J. Geophys. Res., 81, 1847-1856, 1976.

Scholz, C. H., and T. Kato, The behavior of a convergent plate boundary: Crustal deformation in the south Kanto district, Japan, J. Geophys. Res., 83, 783-797, 1978.

Solomon, S. C., N. H. Sleep and R. M. Richardson, On the forces driving plate tectonics: inferences from absolute plate velocities and intraplate stress, R. Astron. Soc. Geophys. J., 42, 769-801, 1975 .

Solomon, S. C., N. H. Sleep, and D. M. Jurdy, Mechanical models for absolute plate motions in the early tertiary, J. Geophys. Res., 82, 203-212, 1977.

Uyeda, S., and H. Kanamori, Back-arc opening and the mode of subduction, J. Geophys. Res., in press, 1979.

\section{Regional Tectonics}

Aggarwal, Y. P., and L. R. Sykes, Earthquakes, faults, and nuclear power plants in southern New York and northern New Jersey, Science, $200,425-429,1978$.

Armbruster, J., I. Seeber, and K. H. Jacob, The northwestern termination of the Himalayan mountain front: Active tectonics from microearthquakes, J. Geophys. Res., 83, 269-282, 1978.

Ben-Menahem, A., A. Nur, and M. Vered, Tectonics, selsmicity and structure of the AfroEurasian junction - The breaking of an incoherent plate, Phys. Earth Planet. Inter., $12,1-50,1976$.

Bird, P., Initiation of intracontinental subduction in the Himalaya, J. Geophys. Res., 83, 4975-4987, 1978.

B $1 \overrightarrow{\text { rd, }}$ P., M. N. Toksöz, and N. H. Sleep, Thermal and mechanical models of continent-continent convergence zones, J. Geophys. Res., 80, 4405-4416, 1975.

Chandra, U., Earthquakes of peninsular India A seismotectonic study, Seismol. Soc. Am., Bu11., 67, 1387-1413, 1977.

Chandra, U., Seismicity, earthquake mechanisms and tectonics along the Himalayan mountian range and vicinity, Phys. Earth Planet. Inter., 16, 109-131, 1978.

Chapman, M.E., and S. Solomon, North AmericanEurasian plate boundary in northeast Asia, J. Geophys. Res., 81, 921-930, 1976.

Chen, W. P., and P. Mo1nar, Seismic moments of major earthquakes and the average rate of slip in central Asia, J. Geophys. Res., 82, 2945-2969, 1977.

Das, S., and J. R. Filson, on the tectonics of Asia, Earth Planet. Sci. Lett., 28, 241 $253,1975$.

Dewey, J. W., Seismicity of northern Anatolia, Seismo1. Soc. Am., Bu11., 66, 843-868, 1976.

Forsyth, D. W., Fault plane solutions and tectonics of the south Atlantic and Scotia Sea, J. Geophys. Res., 80, 1429-1443, 1975.

Freidline, R. A., R. B. Smith, and D. D. 
B1ackwe11, Selsmicity and contemporary tectonics of the Helena, Montana area, Seismol. Soc. Am., Bul1., 66, 81-95, 197.6 .

Jacob, K. H., and R. C. Quittmeyer, The Makran region of Pakistan and Iran: Trench-arc system with active plate subduction, Geodynamics of Pakistan, Memoir II, Geological Survey of Pakistan, in press, 1978.

Johnson, T.L., J. Madrid and T. Koczynski, A study of microseismicity in northern $\mathrm{Baja}$ California, Mexico, Selsmol. Soc. Am., Bull., 66, 1921-1929, 1976 .

Jones, P. R., and S. H. Johnson, Sonobuoy array measurements of active faulting on the Gorda ridge, J. Geophys. Res., 83, 3435-3440, 1978.

Jordan, T. H., The present-day motions of the Carlbbean plate, J. Geophys. Res., 80, 4433$4439,1975$.

Klein, F. W., P. Einarsson, and M. Wyss, The Reykjanes penninsula, Iceland, earthquake swarm of September 1972 and its tectonic significance, J. Geophys. Res., 82, 865-888, 1977.

Molnar, P., and P. Tapponnier, Cenozoic Tectonics of Asia: Effects of a continental collision, Science, 189, 419-426, 1975.

Menke, W. H., and K. H. Jacob, Selsmicity patterns in Pakistan and northwestern India associated with continental collision, Seismol. Soc. Am., Bul1,, 66, 1695-1711, 1976.

Pascal, G., B. L. Isacks, M. Barazangi, and J. Dubois, Precise relocations of earthquakes and seismotectonics of the New Hebrides Island arc, J. Geophys. Res., 83, 4957-4973, 1978.

Plafker, G., Tectonic aspects of the Guatemala earthquake of $4 \mathrm{Feb}, 1976$, Science, 193, 1201-1208, 1976.

Rowlett, H., and J. Kelleher, Evolving seismic and tectonic patterns along the Western margin of the Philippine sea plate, J. Geophys. Res., 81, 3518-3524, 1976.

Sbar, M. L., and L. B. Sykes, Seismicity and lithospheric stress in New York and adjacent areas, J. Geophys. Res., 82, 5771-5786, 1977.

Seeber, L., and K. H. Jacob, Microearthquake survey of northern Pakistan: Preliminary results and tectonic implications, Colloques Internationaux du Centre National de la Recherche Sclentifique, No. 268, 1976.

Sharman, G. F., M. S. Reichle, and J. N. Brune, A detalled study of relative plate motion in the Gulf of California, Seismol. Soc. Am., Bull., in press, 1979 .

Sieh, K. E., Prehistoric large earthquakes produced by slip on the San Andreas fault at Pallett Creek, California, J. Geophys. Res., 83, 3907-3939, 1978.

Silver, E. A., and J. C. Moore, The Molucca sea collision zone, Indonesia, J. Geophys. Res., 83, 1681-1691, 1978.

Smith, R. B., Intra-plate tectonics of the Western North American plate, Tectonophysics, 37, 323-336, 1977.

Smith, R. B., R. T. Shuey, J. R. Pelton, and J. P. Bailey, Yellowstone hot spot: Contemporary tectonics and crustal properties from earthquake and aeromagnetic data, J. Geophys. Res., 82, 3665-3676, 1977.
Stein, S., and E. A. Oka1, Seismicity and tectonics of the Ninetyeast ridge area: Evidence for internal deformation of the Indian plate, J. Geophys. Res., 83, 22332245, 1978 .

Tapponnier, P., and P. Molnar, Active faulting and tectonics in China, J. Geophys. Res., $\underline{82}$, 2905-2930, 1977.

Tatham, R. H., D. W. Forsyth and L. R. Sykes, The occurrence of anomalous seismic events in eastern Tibet, R. Astron. Soc., Geophys. J., 45, 451-481, 1976 .

Trimble, A. B., and R. B. Smith, Seismicity and contemporary tectonics of the Hebgen Lake Yellowstone park region, J. Geophys. Res., $\underline{80}$, 733-741, 1975.

York, J. E., R. Cardwell, and J. Ni, Seismicity and Quaternary faulting in China, Seismol. Soc. Am., Bul1., 66, 1983-2001, 1976.

Aseismic Deformation, Asthenosphere

Anderson, D. L., Accelerated plate tectonics, Science, 187, 1077-1079, 1975.

Dahlen, F. A., The passive influence of the oceans upon the rotation of the earth, R. Astron. Soc., Geophys. J., 46, 363-406, 1976 .

Kanamori, H., Seismic and aseismic slip along subduction zones and their tectonic implications, in Island Arcs, Deep Sea Trenches, and Back-Arc Basins, edited by M. Talwaui

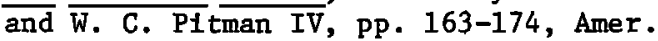
Geophys. Un., 1977.

Kanamori, H., Are earthquakes a major cause of the Chandler wobble? Nature, 262, 254-255, 1976 .

Kanamor1, H., The energy release in great earthquakes, J. Geophys. Res., 82, 2981-2987, 1977.

Kanamori, H., and D. L. Anderson, Amplitude of the earth's free oscillations and long-period characteristics of the earthquake source, J. Geophys. Res., 80, 1075-1078, 1975.

Kanamori, H., and G. S. Stewart, A slow earthquake, Phys. Earth Planet. Inter., in press, 1979 .

Melosh, H. J., Nonlinear stress propagation in the earth's upper mantle, J. Geophys. Res., 81, 5621-5632, 1976.

Melosh, J., Shear stress on the base of a Iithospheric plate, Pure Applied Geophysics, $115,429-439,1977$.

O'Conne11, R. J., and A. M. Dziewonski, Exictation of Chandler wobble by large earthquakes, Nature, 262, 259-262, 1976.

Press, R., and Briggs, P., Chandler wobble, earthquakes rotation and geomagnetic changes, Nature, 256, 270-273, 1975.

Rundle, J. B., and D. D. Jackson, A viscoelastic relaxation model for post-seismic deformation from the San Francisco earthquake of 1906, Pure Applied Geophysics, I15, 401$411,1977$.

Sacks, I. S., S. Suyehiro, A. T. Linde, and J. A. Snoke, Slow earthquakes and stress redistribution, Nature, 275, 599-602, 1978.

Savage, J. C., and W. H. Prescott, Asthenosphere readjustment and the earthquake cycle, J. Geophys. Res., 83, 3369-3376, 1978.

Savage, J. C., and W. H. Prescott, Comment on 
Nonlinear stress propagation in the earth's upper mantle by H. J. Melosh, J. Geophys. Res., 83, 5005-5007, 1978.

Smith, M. L., Wobble and nutation of the earth, R. Astron. Soc., Geophys. J., 50, 103-140, 1977.

Thatcher, W., and J. B. Rundle, A model for the earthquake cycle in underthrust zones, J. Geophys. Res., in press, 1979.

Wilson, C. R., and R. A. Haubrich, Earthquakes, weather and wobble, Geophys. Res. Lett., 4, 283-284, 1977.

\section{Subduction Zones}

Barazang1, M., and B. L. Isacks, Spatial distribution of earthquakes and subduction of the Nazca plate beneath South America, Geology, 4, 686-692, 1976.

Billington, S., and B. L. Isacks, Identification of fault planes associated with deep earthquakes, Geophys. Res. Lett., 2, 63-66, 1975.

Cardwel1, R. K., and B. L. Isacks, Geometry of the subducted 1ithosphere beneath the Banda Sea in eastern Indonesia from seismicity and fault plane solutions, J. Geophys. Res., 83, 2825-2838, 1978.

Chung, Wai-Ying, and $\mathrm{H}$. Kanamori, Subduction process of a fracture zone and aseismic ridges - the focal mechanism and source characteristics of the New Hebrides earthquake of 1969 January 19 and some related events, R. Astron. Soc., Geophys. J., 54, $221-240,1978$

Engdah1, E. R., Selsmicity and plate subduction in the central Aleutians, in Island Arcs, Deep Sea Trenches and Back-Arc Basins, edited by M. Talwanj and W. C. Pitman IV, pp. 259-271, Am. Geophys. Union, 1977.

EngdahI, E. R., and C. H. Scholz, A dpuble Benioff zone beneath the central Aleutians: An unbending of the lithosphere, Geophys. Res. Lett., 4, 473-476, 1977.

Isacks, B. L., and M. Barazang1, Geometry of Benioff zones; lateral segmentation and downwards bending of the subducted lithosphere, in Island Arcs, Deep Sea Trenches and Back-Arc Basins, edited by M. Talwani and W. C. Pitman IV, pp. 99-114, Am. Geophys. Union, 1977.

Isacks, B., M. Barazangi, J. York, C. Stephens, R. Louat, B. Pouloise, and J. Dubois, Tectonics of the central New Hebrides island arc: Spatial distribution of earthquakes from local seismograph networks and focal mechanisms, Geology, in press, 1979.

Ke11eher, J., and W. McCann, Buoyant zones, great earthquakes and unstable boundaries of subduction, J. Geophys. Res., 81, 4885-4896, 1976.

Kelleher, J., and W. McCann, Bathymetric highs and the development of convergent plate boundaries, in Island Arcs, Deep Sea Trenches and Back-Arc Basins, edited by M. Talwani and W. C. Pitman IV, pp. 115-122, Am. Geophys . Union, 1977.

McCann, W. R., S. P. Nishenko, L. R. Sykes, and J. Krause, Seismic gaps and plate tectonics: seismic potential for major plate boundaries, Proceedings of Conference VI Methodology for
Identifying Seismic Gaps and Soon-to-Break Gaps, U.S. Geological Survey Open-File Report 78-943, 441-584, 1978.

McGarr, A., Seismic moments and volume changes, J. Geophys. Res., 81, 1487-1494, 1976.

McGarr, A., Seismic moments of earthquakes beneath island arcs, phase changes, and subduction velocities, J. Geophys. Res., 82, 256-264, 1977.

Nishenko, S., and W. McCann, Large thrust earthquakes and tsunamis: Implications for the development of fore arc basins, $\mathrm{J}$. Geophys. Res., 84, 573-584, 1979.

Spence, W., The Aleutian arc: Tectonic blocks, episodic subduction, strain diffusion, and magma generation, J. Geophys. Res., 82, 21.3-230, 1977.

Vogt, P. R., A. Lowrie, D. R. Bracey, and R. N. Hey, Subduction of aseismic oceanic ridges: Effects on shape, seismicity and other characteristics of consuming plate boundaries, Special paper 172, Geol. Soc. Am., 59 p, 1976.

\section{ADDITIONAL REFERENCES}

\section{Source Mechanism Studies}

Acharya, H. K., Mindanao earthquake of August 16, 1976: Preliminary seismological assessment, Seismo1. Soc. Am., Bu11., 68, 1459-1468, 1978.

Bouchon, M., A dynamic source model for the San Fernando earthquake, Seismol. Soc. Am., Bu11., 68, 1555-1576, $197 \overline{8}$.

Einarsson, P., F. W. Klein, and S. Bjornsson, The Borgarfjördur earthquakes of 1974 in west Iceland, Selsmol. Soc. Am., Bull., 67, 187-208, 1977.

Mendiguren, J. A., and K. Ak1, Source mechanism of the deep Colombian earthquake of July 31, 1970, from the free oscillation data, $R$. Astron. Soc., Geophys. J., 55, 539-556, 1978.

Pennington, W. D., and B. L. Isacks, Analysis of short-period waveforms of $P$ phases from deep-focus earthquakes beneath the Fiji islands, R. Astron. Soc., Geophys. J., 56, $19-40,1979$.

Pitt, A. M., C. S. Weaver, and W. Spence, The Yellowstone park earthquake of June 30, 1975, Seismol. Soc. Am., Bull., 69, 187-205, 1979.

Synthesis and Mode1s

Sykes, L. R., Intraplate selsmicity, reactivation of preexisting zones of weakness, alkaline magmatism, and other tectonism postdating continental fragmentation, Rev. Geophys. Space Phys., 16, 621-688, 1978.

\section{Regional Tectonics}

Molnar, P., and P. Tapponnier, Active tectonics of Tibet, J. Geophys. Res., 83, 5361-5375, 1978.

Ni, J., and J. E. York, Late Cenozoic tectonics of the Tibetan plateau, J. Geophys. Res., 83, 5377-5384, 1978 .

Sieh, K. E., Slip along the San Andreas fault associated with the great 1857 earthquake, Se ismo1. Soc. Am., Bul1., 68, 1421-1448, 1978. 
Aseismic Deformation, Asthenosphere

Rundle, J. B., Viscoelastic crustal deformation by finite quasi-static sources, J. Geophys. Res., 83, 5937-5945, 1978.

Subduction Zones

Billington, S., B. L. Isacks, and M. Barazangi, Spatial distribution and focal mechanisms of mantle earthquakes in the Hindu Kush-Pamir region: A contorted Benioff zone, Geology, 5, 699-704, 1977 .

James, D. E., Subduction of the Nazca plate beneath central Peru, Geology, 6, 174-178, 1978.

VOL. 17 , NO. 2
Molnar, P., D. Freedman, J. S. F. Shih, Lengths of intermediate and deep seismic zones and temperatures in downgoing slabs of 1ithosphere, R. Astron. Soc., Geophys. J., 56, 41-54, 1979.

Molnar, P., and D. Gray, Subduction of continental 1ithosphere: Some constraints and uncertainties, Geology, 7, 58-62, 1979.

Sacks, I. S., Interrelationships between volcanism, seismicity, and anelasticity in western South America, Tectonophysics, 37, $131-139,1977$.

Snoke, J. A., I. S. Sacks, and H. Okada, Determination of the subducting lithosphere boundary by use of converted phases, Seismol. Soc. Am., Bull., 67, 1051-1060, 1977.

\section{EARTHQUAKE PREDICTION}

Peter L. Ward

U.S. Geological Survey, Menlo Park, California 94025

Earthquake prediction, hardly taken seriously as science in the United States before 1971, reached fledgling status in the perlod 1975 to 1978. By late 1974, most U.S. researchers in seismology were agreeing that earthquakes might be predictable on a scientific basis. Cautious optimism had in fact turned to rampant enthusiasm anong some workers as evidence accumulated for many possible earthquake precursors and the theory of dilatancy seemed to explain most observations (see summaries by Bolt and Wang, 1975; Healy, 1975; Kisslinger and Wyss, 1975). Slower progress since 1974 has dampened the euphoria felt by some but a much more solid and broad foundation for a Prediction Program has now been constructed and a number of important cornerstones laid.

A new sense of urgency and relevancy for prediction research was created in December, 1975, when Castle et al. (1976) presented evidence that the elevation of a 12,000 square kilometer area in southern California had increased by 15 to $25 \mathrm{~cm}$ during the $1960^{\prime} \mathrm{s}$. Because this uplift lay astride a section of the San Andreas fault that has been essentially aseismic since a devastating earthquake in 1857 and because uplifts have been reported before other damaging earthquakes (e.g. Castle et al., 1974), the ominous suggestion was made that this uplift could be precursory to the next great California earthquake. Although scientists could not and still cannot be sure that the uplift is a precursor, concern was expressed from households in the uplifted area all the way to the White House and research scientists were

This paper is not subject to U.S. copyright. Published in 1979 by the American Geophysical Union. suddenly asked to interact closely with public leaders, news media, and the general public. Staff of the U.S. Geological Survey (USGS) were invited to brief the President's Advisory Panel on Anticipated Advances in Science and Technology. The Director of the USGS met with the staff of the Governor of California to discuss implications of the observed uplift. The USGS and the National Science Foundation (NSF) were asked to transfer, for one year, \$2.6 million from other programs over to earthquake research related to the Southern California Uplift and to develop a rationale for a national Earthquake Hazards Reduction Program (EHRP). A panel, convened by the President's Science Advisor, issued such a rationale (anonymous, 1976), which, together with the initiatives of Congress and the feeling of most seismologists that substantial progress was possible, helped bring about a threefold increase in funds during 1978 (Hamliton, 1978). Funding for earthquake prediction increased to a national level of $\$ 15.8$ million, and the level of effort in the whole Earthquake Hazards Reduction Program funded by the USGS and NSF rose to a total of $\$ 53.2$ million including prediction, hazards assessment, earthquake engineering, induced seismicity, fundamental studies of earthquakes, and research on how to stimulate the utilization of scientific results by the general public as well as studies of the socioeconomic impact of predictions.

Continued analysis of the uplift showed that between late 1972 and early 1974 the area of uplift increased to more than 50,000 square kilometers and the maximum uplift reached $45 \mathrm{~cm}$ (Castle, 1978; Holdahl, 1977). Then, by 1976, the whole area subsided to less than 50 percent 